Neuro Images
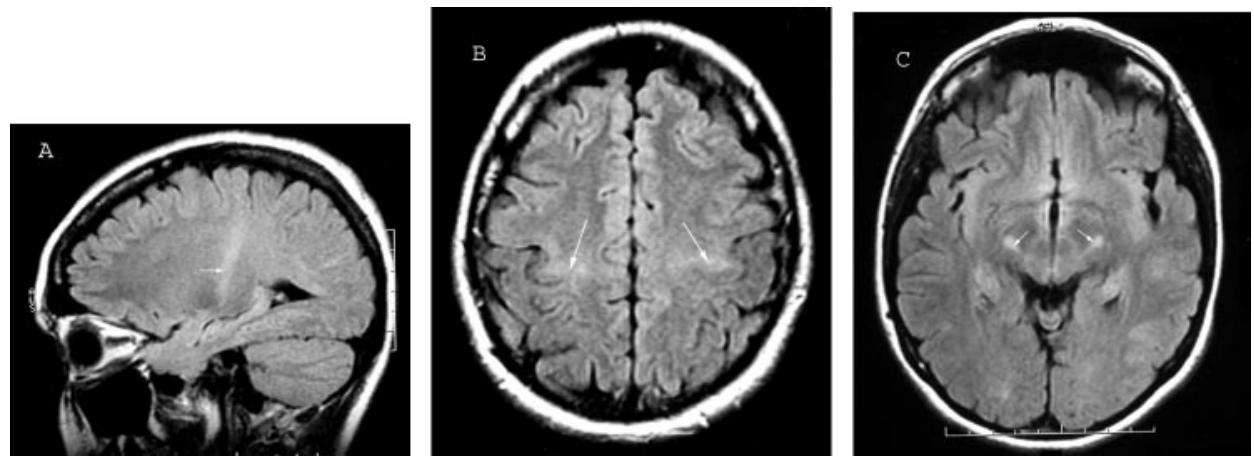

Figure. (A) T1-weighted sagittal image shows hyperintense signal along the left corticospinal tract. This striking appearance is also present on the opposite hemisphere. (B) Axial FLAIR image shows hyperintensity of precentral gyrus bilaterally. (C) Axial FLAIR image shows hyperintense corticospinal tract at the crus cerebri. This series of MR images clearly demonstrated bilateral corticospinal tract involvement in amyotrophic lateral sclerosis.

\section{MRI in ALS: Corticospinal tract hyperintensity}

Yong Chern Lee, MBBS, Romesh Markus, MBChB, FRACP, and Andrew Hughes, MD, FRACP, Heidelberg, Victoria, Australia

A 32-year-old woman with no family history presented with 12 months of progressive left upper limb weakness. Examination revealed moderate wasting and pyramidal weakness in all muscle groups in the left upper limb, especially the shoulder girdle and

Address correspondence and reprint requests to Dr. Yong Chern Lee, Neurology Department, 3KZ Building, Austin and Repatriation Medical Centre, Studley Road, Heidelberg 3084, Melbourne, Victoria, Australia; e-mail: yongchern@yahoo.com intrinsic hand muscles. Mild pyramidal weakness was also noted in the left lower limb. No fasciculation was noted. She was hypertonic and hyperreflexic in all four limbs. Clonus and upgoing plantar response were elicited bilaterally. Sensory and cranial nerve examinations were unremarkable. Neurophysiology and MRI studies (figure) supported the diagnosis of amyotrophic lateral sclerosis (ALS). Recent neuroimaging studies have demonstrated hyperintense signals on T2-weighted and fluid-attenuated inversion recovery images along the corticospinal tract in some patients with ALS. ${ }^{1}$ This is thought to be due to a dying back process.

1. Hecht MJ, Fellner F, Fellner C, Hilz MJ, Heuss D, Neundorfer B. MRIFLAIR images of the head show corticospinal tract alterations in ALS patients more frequently than T2-, T1- and proton-density-weighted images. J Neurol Sci 2001;186:37-44. 


\title{
Neurology
}

\author{
MRI in ALS: Corticospinal tract hyperintensity \\ Yong Chern Lee, Romesh Markus and Andrew Hughes \\ Neurology 2003;61;1600 \\ DOI 10.1212/01.WNL.0000096015.48322.2A
}

This information is current as of December 8, 2003

\section{Updated Information \& Services}

References

Citations

Subspecialty Collections

Permissions \& Licensing

Reprints including high resolution figures, can be found at: http://n.neurology.org/content/61/11/1600.full

This article cites 1 articles, 0 of which you can access for free at: http://n.neurology.org/content/61/11/1600.full\#ref-list-1

This article has been cited by 3 HighWire-hosted articles: http://n.neurology.org/content/61/11/1600.full\#\#otherarticles

This article, along with others on similar topics, appears in the following collection(s):

All Imaging

http://n.neurology.org/cgi/collection/all_imaging

Amyotrophic lateral sclerosis

http://n.neurology.org/cgi/collection/amyotrophic_lateral_sclerosis_ MRI

http://n.neurology.org/cgi/collection/mri

Information about reproducing this article in parts (figures,tables) or in its entirety can be found online at:

http://www.neurology.org/about/about_the_journal\#permissions

Information about ordering reprints can be found online: http://n.neurology.org/subscribers/advertise

Neurology ${ }^{\circledR}$ is the official journal of the American Academy of Neurology. Published continuously since 1951, it is now a weekly with 48 issues per year. Copyright . All rights reserved. Print ISSN: 0028-3878. Online ISSN: 1526-632X.

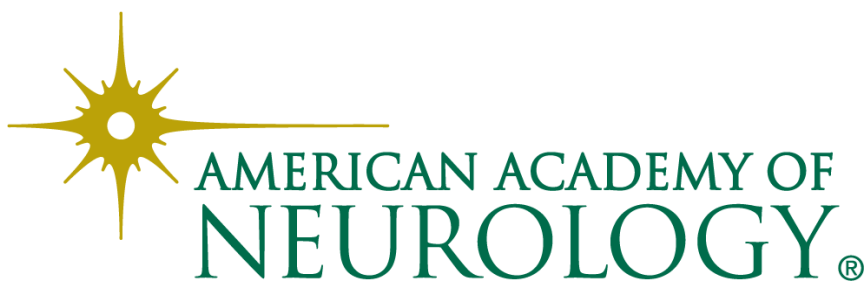

